\title{
The nymphs of the genus Camelobaetidius Demoulin (Ephemeroptera : Baetidae) in Brazil : new species, new records, and key for the identification of the species
}

\author{
F.F. Salles ${ }^{1 *}$, J.E. Serrão ${ }^{2}$ \\ ${ }^{1}$ Universidade Federal de Viçosa, Departamento de Biologia Animal, 36571-000, Viçosa, MG, Brazil. \\ ${ }^{2}$ Universidade Federal de Viçosa, Departamento de Biologia Geral, 36571-000, Viçosa, MG, Brazil.
}

\begin{abstract}
Three new species of Camelobaetidius Demoulin (Ephemeroptera : Baetidae), C. hamadae sp. n., C. lassance sp. n., and $C$. maranhensis sp. n., are described based on nymphs from Brazil. Some of the diagnostic characters of the new taxa are : $C$. hamadae sp. n., two thoracic gills at base of forelegs and claws with 36-37 denticles ; C. lassance sp. n., claws with approximately 60 denticles and posterior margin of terga with few, large and elevated spines ; C. maranhensis sp. n., pronotum with medial pair of tubercles and terminal filament shorter than 10th abdominal segment. Camelobaetidius cayumba (Traver \& Edmunds), C. matilei Thomas \& Perú, and C. tuberosus Lugo-Ortiz \& McCafferty, are recorded for the first time from Brazil. A key to the species of Camelobaetidius recorded from Brazil based on nymphs is presented.
\end{abstract}

Keywords : Ephemeroptera, Baetidae, Camelobaetidius, taxonomy, Brazil.

\section{Introduction}

Camelobaetidius Demoulin is a Panamerican genus of small minnow mayflies (Ephemeroptera : Baetidae) with 25 species currently recorded from South America. Except for a few countries, where they are probably not reported due the lack of studies on the fauna of Baetidae (e.g. Ecuador, Chile and Guiana), all South American countries have records of nominal species of Camelobaetidius (Traver \& Edmunds 1968, Lugo-Ortiz \& McCafferty 1999a,b, Dominique et al. 2001, 2002, Dominique \& Thomas 2002, Thomas et al. 2003a, b, Nieto 2002, 2003, Salles et al. 2005b).

In Brazil, the following species of Camelobaetidius have been reported : C. anubis (Traver \& Edmunds), C. billi Thomas \& Dominique in Dominique et al., $C$. francischettii Salles, Andrade \& Da-Silva, C. janae Dominique \& Thomas in Dominique et al., C. leent-

\footnotetext{
* Corresponding author :

E-mail : ffsalles@gmail.com
}

vaari Demoulin, C. mantis Traver \& Edmunds, $C$. phaedrus (Traver \& Edmunds), and C. serapis (Traver \& Edmunds) (Traver \& Edmunds 1968, Salles \& Dias 2004, Salles et al. 2004, Salles et al. 2005a, b). Among material collected in several areas of Brazil, including the poorly documented Northeast and Central-West regions, three new species of Camelobaetidius, and three species never reported from the country were found. In the present paper, besides the description and record of these species, we present for the first time a key to separate the nymphs of the Brazilian species of Camelobaetidius.

Given the great number of species of the genus, and the amount of undocumented areas within the country, it is probable that some species of Camelobaetidius remain to be found and/or described from Brazil. To avoid misidentifications, we also present a diagnosis for the 14 species currently reported from the country. Diagnoses were based primarily on four characters that usually are adequate for distinguishing species of $\mathrm{Ca}$ melobaetidius : shape of the inner margin of the second segment of labial palp ; presence or absence of a thoracic gill at the base of foreleg; number of denticles 
on the claws ; and the length of the terminal filament. In cases where these characters are not adequate for identification, or the species presents some remarkable features, other characteristics are also presented. The list of the species is presented in alphabetical order. The material is housed in the following institutions : Entomological Collection of the Instituto Nacional de Pesquisas da Amazônia, Amazonas, Brazil (INPA) ; Museu Nacional, Universidade Federal do Rio de Janeiro, Rio de Janeiro, Brazil (MNRJ); and FundaciónInstituto Miguel Lillo, Tucumán, Argentina (IFML).

\section{Results and Discussion}

\section{Camelobaetidius anubis (Traver \& Edmunds,} 1968)

Diagnosis : inner margin of the second segment of labial palp pointed ; thoracic gill present at base of fo- relegs ; claws with 20-27 denticles ; terminal filament about as long as cerci ; length of body 6.5-10.0 mm.

Brazilian records (Fig. 1) : Guarapuava and Serra do Purunã, Paraná State ; Seara, Ipumirim and Campos Novos, Santa Catarina State ; Araponga and Bocaina de Minas, Minas Gerais State ; Ribeirão Grande, São Paulo State ; Itatiaia and Teresópolis, Rio de Janeiro State.

Remarks : This species was described based exclusively on nymphs from Southern Brazil by Traver \& Edmunds (1968). Later, Salles et al. (2003, 2004) extended the known distribution of the species to Northern Brazil, and Nieto (2003) recorded it from Argentina, describing the adults for the first time.

Camelobaetidius billi Thomas \& Dominique in Dominique et al., 2001

Diagnosis : inner margin of the second segment of labial palp rounded ; thoracic gill present at base of fo-
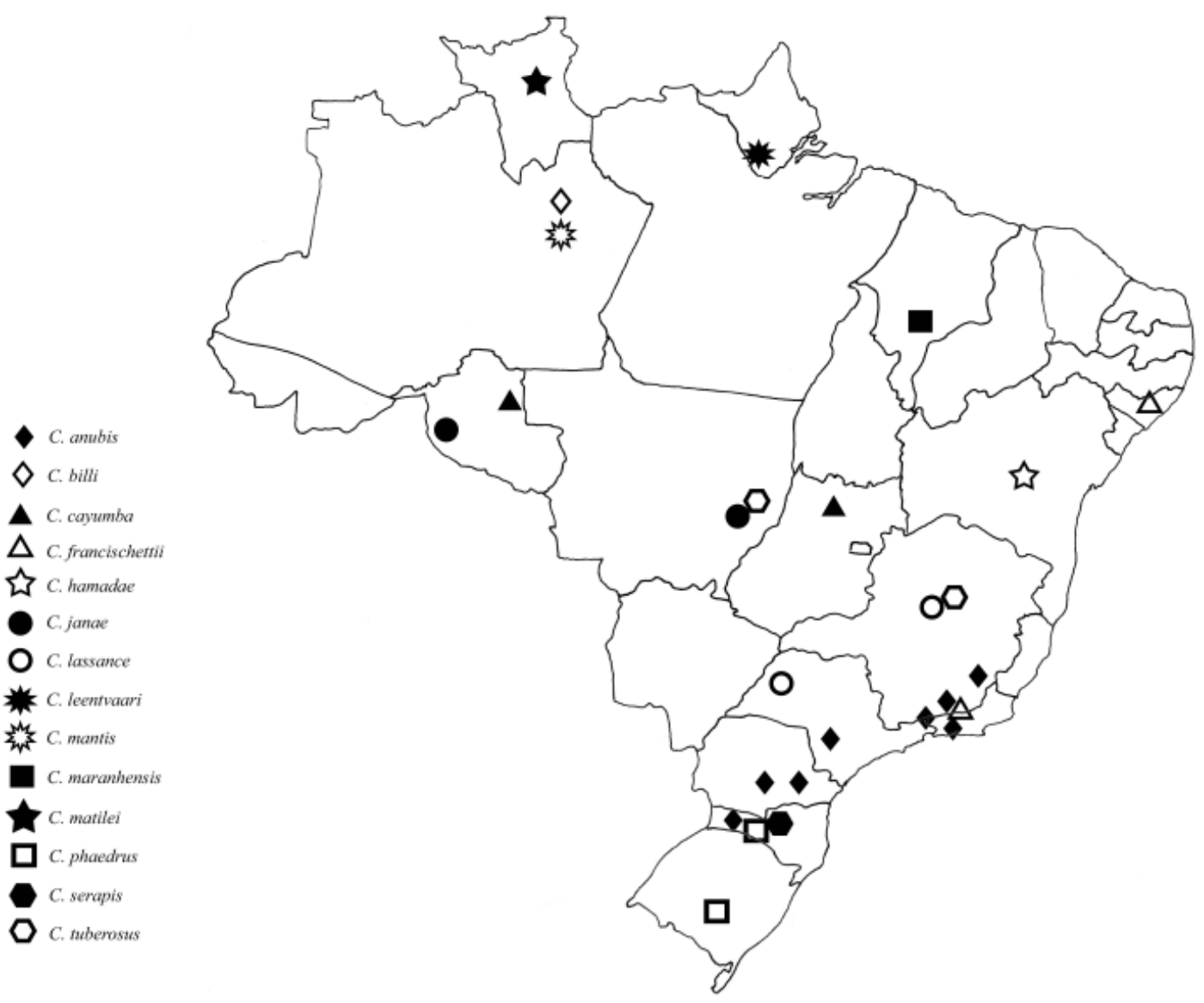

Fig. 1. Geographic distribution of the species of Camelobaetidius recorded from Brazil. 
relegs ; claws with approximately 31 denticles ; terminal filament reduced.

Brazilian records (Fig. 1) : Presidente Figueiredo, Amazonas State.

Remarks : This species was originally described based on nymphs from French Guiana (Dominique et al. 2001). Salles \& Dias (2004) recently described the adults based on material from Northern Brazil.

\section{Camelobaetidius cayumba (Traver \& Edmunds, 1968)}

Diagnosis : inner margin of the second segment of labial palp pointed ; thoracic gill absent at base of forelegs ; claws with 15-18 denticles ; terminal filament about as long as cerci.

Brazilian records (Fig. 1) : Rio das Almas, Goiás State ; Ji-Paraná, Rondônia.

Remarks : C. cayumba, described originally from Peru by Traver \& Edmunds (1968), was recently redescribed by Thomas et al. (2001). These are the first records of C. cayumba from Brazil, extending considerably its known distribution to the south.

Material examined : Goiás, Rio das Almas, between $14^{\circ} 43^{\prime} 07^{\prime \prime} \mathrm{S} / 49^{\circ} 01^{\prime} 24^{\prime \prime} \mathrm{W}$ and $14^{\circ} 42^{\prime} 35^{\prime}$ 'S $/ 49^{\circ} 01^{\prime}$ 56”W, 12/x/1996, 4 nymphs ; Rondônia, Ji- Paraná, Rio Urupá, Balneário Bernardino, $10^{\circ} 07^{\prime} 16.9^{\prime}$ 'S, 61 ${ }^{\circ} 54^{\prime} 32.1^{\prime \prime} \mathrm{W}, 02 / \mathrm{viii} / 2002$, N. Hamada leg., 2 nymphs and 2 nymphal exuvia.

Camelobaetidius francischettii Salles, Andrade \& Da-Silva, 2005

Diagnosis : segment two of labial palp with distomedial process rounded and strongly produced ; forefemora with prominent protuberance ; foretibiae with indentation at apex ; ventral margin of forefemora and foretibiae entirely scattered with spines ; claws with 34 to 37 denticles ; small thoracic gill at the base of forelegs ; prosternum with a single, medial protuberance ; terminal filament about as long as the length of the $10^{\text {th }}$ abdominal segment.

Brazilian records (Fig. 1) : Piraí, Rio de Janeiro State ; Murici, Alagoas State.

Remarks : $C$. francischettii was described based solely on nymphs from Alagoas and Rio de Janeiro states (Salles et al. 2005b).

Camelobaetidius hamadae Salles \& Serrão, sp. n. (Figs. 1 -13, 37, 40, 45-46)

Mature nymph. Body length : 5.6-6.2 mm. Caudal filaments length : broken off in all nymphs, at least 2.3 $\mathrm{mm}$.
Head. General coloration yellowish, with brownish and whitish marks as in Fig. 2 ; turbinate portion of male compound eyes orange. Antennae brownishtranslucent. Labrum (Fig. 3) with anterodorsal row of 22 long, fine, simple setae, and with few short, fine, simple setae, scattered over surface. Hypopharynx as in Fig. 4. Left mandible (Fig. 5) with incisors protruded and fused, with seven denticles ; prostheca robust, apically denticulate; eight minute, spiniform setae, occasionally bifid, between prostheca and subtriangular process ; subtriangular process wide at base, not strongly produced. Right mandible (Fig. 6) with incisors protruded and strongly fused, with five to six denticles ; prostheca robust, narrower than left prostheca and with row of minute spines ; 16 minute, spinelike setae, between prostheca and mola. Maxillae (Fig. 7) with palp segment one cylindrical; segment two subequal in length to segment one; medial hump with $1+1$ fine, simple, setae. Labium (Figs. 8, 9) with glossae presenting seven fine, simple setae medially, and eight fine, simple setae distally ; paraglossae longer than glossae, apically with two rows of long, apically pectinate setae, dorsally with two robust, simple setae ; segment two of labial palp with distomedial process rounded and strongly produced, inner margin with few, fine, simple setae, and dorsally with five long, fine, simple setae ; segment three scattered with few spinelike setae over surface.

Thorax. Pronotum (Fig. 10) and mesonotum yellowish, with brown marks. Metanotum brown. Pleurae yellowish to light brown. Sterna yellowish. Legs (Fig. 11) with two thoracic gills at base ; femora light brown, with whitish and dark brown marks as in Fig. 11 ; tibiae light brown, ventral margin scattered with few short, acute, simple setae, becoming more abundant and longer at the apex; tarsi brown, ventral margin lighter, with 12 short, acute, simple setae, one subdistal long, robust, simple seta, and one distal robust, simple setae ; claws (Fig. 40) with 36-37 denticles.

Abdomen. General coloration yellowish, with light brown to brownish marks as in Fig. 37. Posterior margin of terga (Figs. 45, 46) with triangular spines. Sterna yellowish. Gills (Fig. 12) whitish, with main trachea pigmented to poorly pigmented. Paraprocts as in Fig. 13. Terminal filament about as long as cerci.

Adults. Unknown.

Type material. Holotype : female mature nymph, body in alcohol, legs and mouthparts mounted on slides. Bahia, Estrada Andaraí - Lençóis. Rio Roncador, $12^{\circ} 41$ '58.5”S 41 21 '28.1"W. N. Hamada (INPA). Paratypes : 12 nymphs, Bahia, Palmeiras, Córrego Conceção dos Gatos, N. Hamada (6 nymphs in INPA, 6 in MNRJ) ; 5 nymphs, Bahia, Mucugê, Rio Cumbuca, 04/viii/2005, N. Hamada (IFML). 


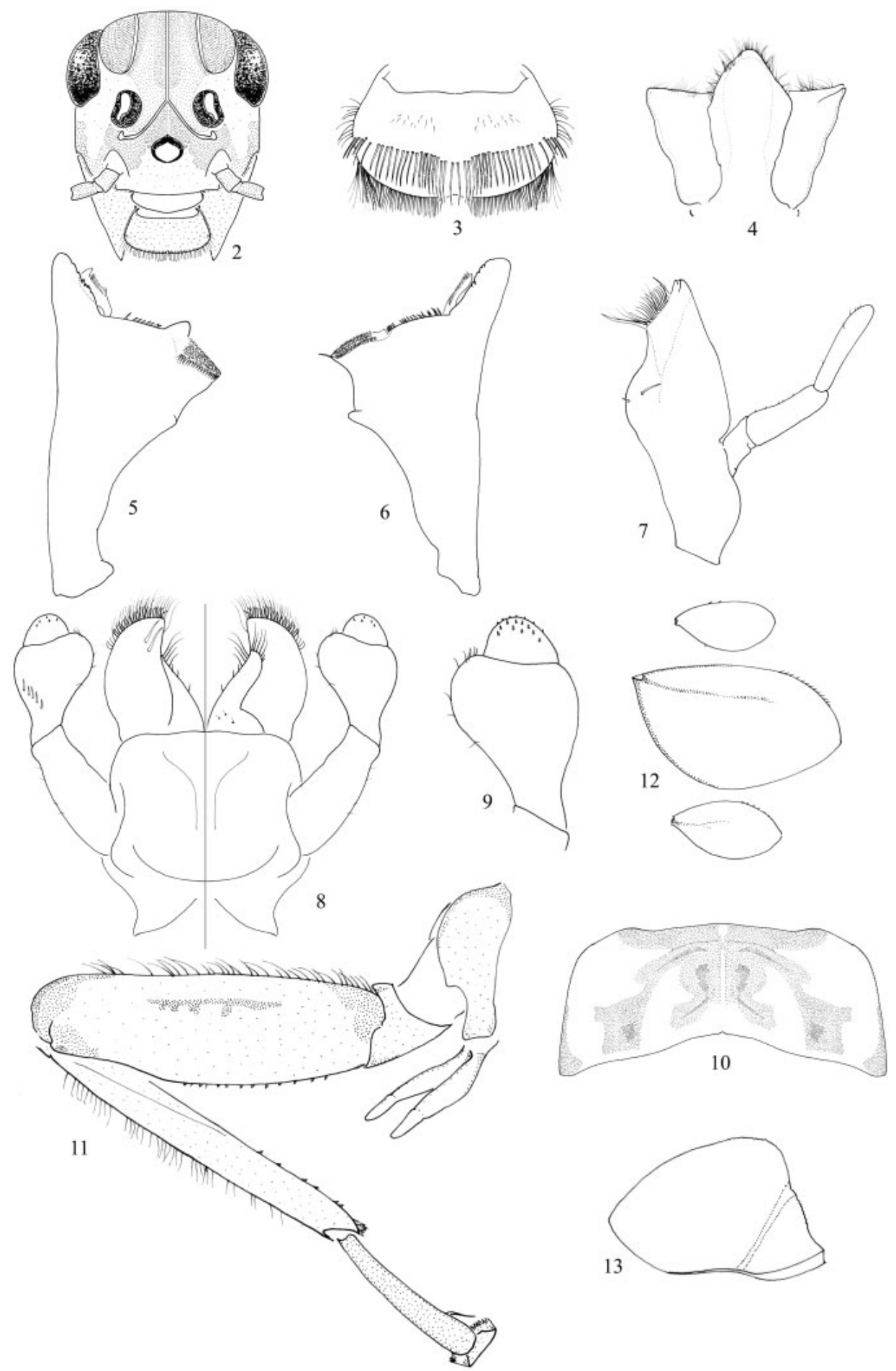

Figs 2-13. Camelobaetidius hamadae sp. n., mature nymph. 2. Head (frontal). 3. Labrum (dorsal). 4. Hypopharynx. 5. Left mandible. 6. Right mandible. 7. Maxilla. 8. (left-dorsal; right-ventral). 9. Labium (detail of labial palp segments two and three). 10. Pronotum. 11. Foreleg. 12. Gills 1, 4, and 7. 13. Paraproct. 


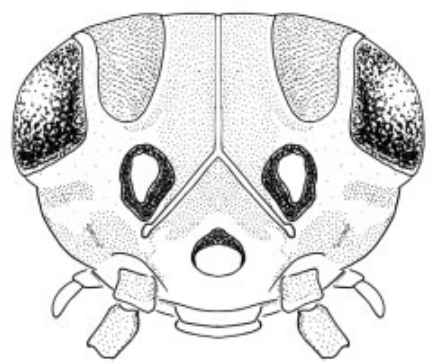

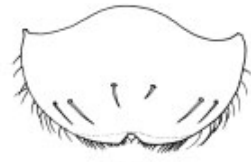

15

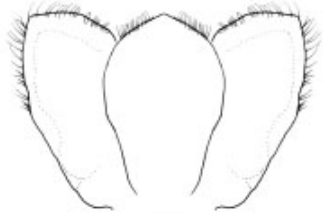

16

14
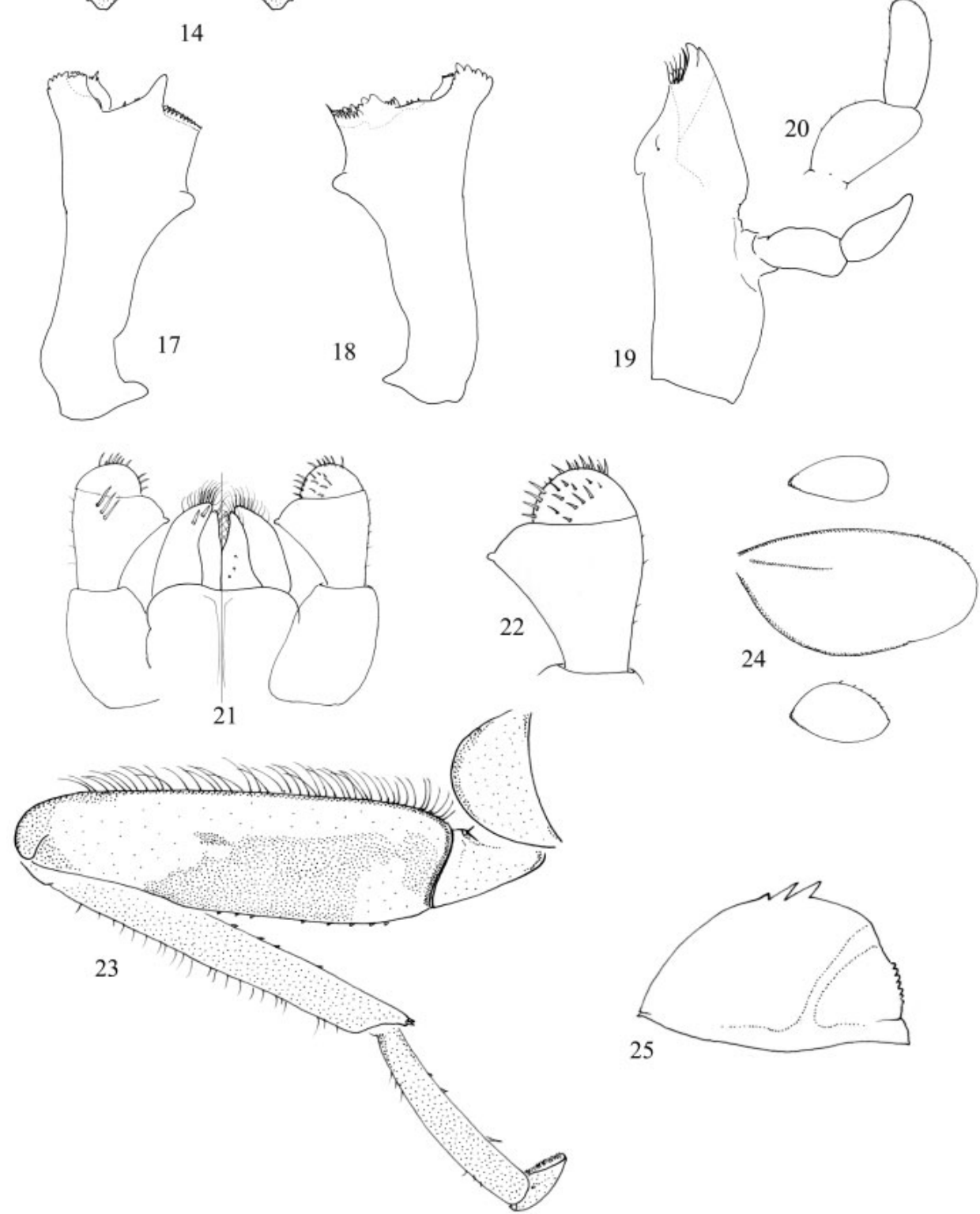

Figs 14-25. Camelobaetidius lassance sp. n., mature nymph. 14. Head (frontal). 15. Labrum (dorsal). 16. Hypopharynx. 17. Left mandible. 18. Right mandible. 19. Maxilla. 20. Maxillary palp segments one and two. 21. Labium (left-dorsal; right-ventral). 22. Labium (detail of labial palp segments two and three). 23. Foreleg. 24. Gills 1, 4, and 7. 25. Paraproct. 

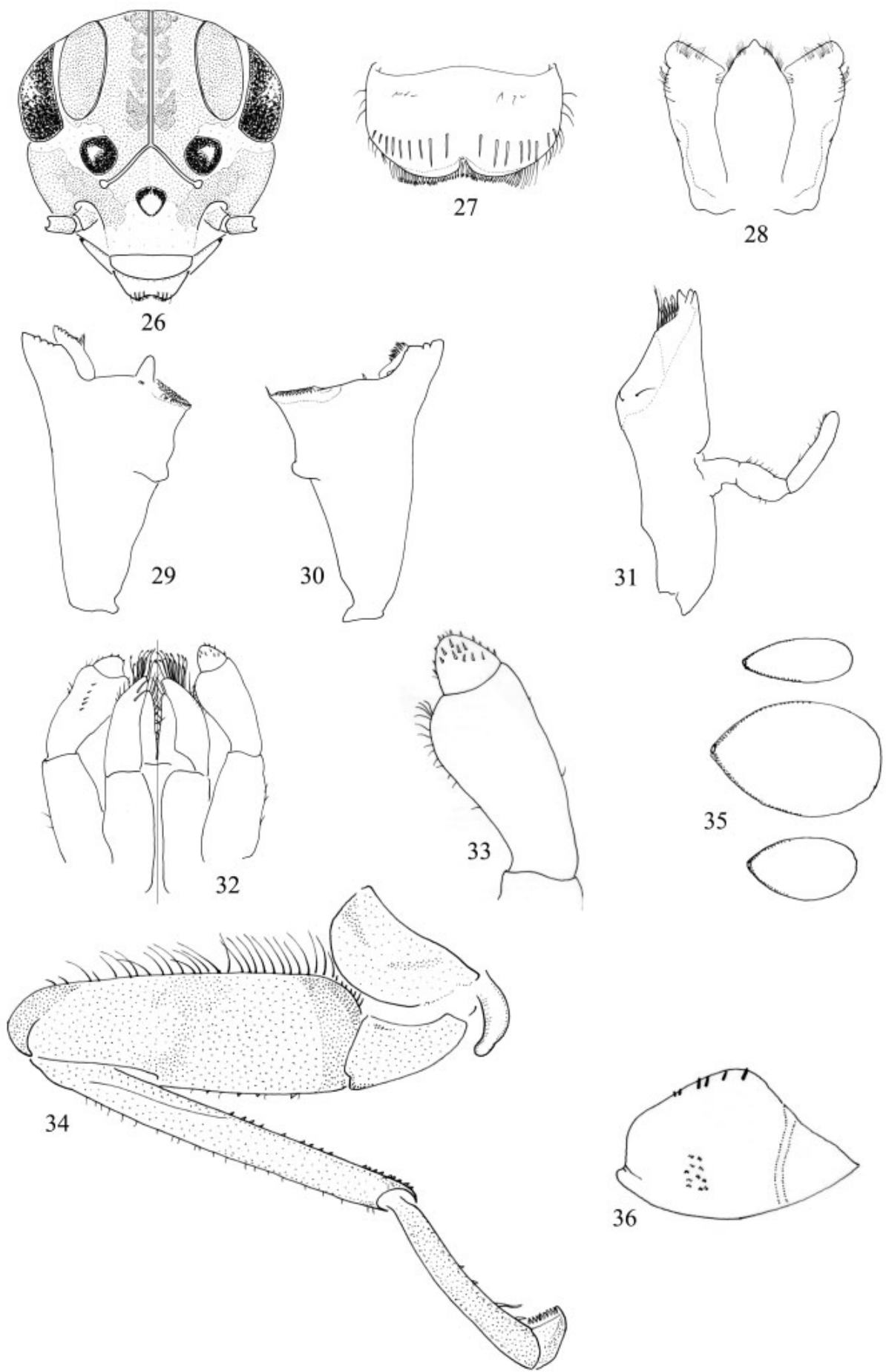

Figs 26-36. Camelobaetidius maranhensis sp. n., mature nymph. 26. Head (frontal). 27. Labrum (dorsal). 28. Hypopharynx. 29. Left mandible. 30. Right mandible. 31. Maxilla. 32. Labium (left-dorsal; right-ventral). 33. Labium (detail of labial palp segments two and three). 34. Foreleg. 35. Gills 1, 4, and 7. 36. Paraproct. 


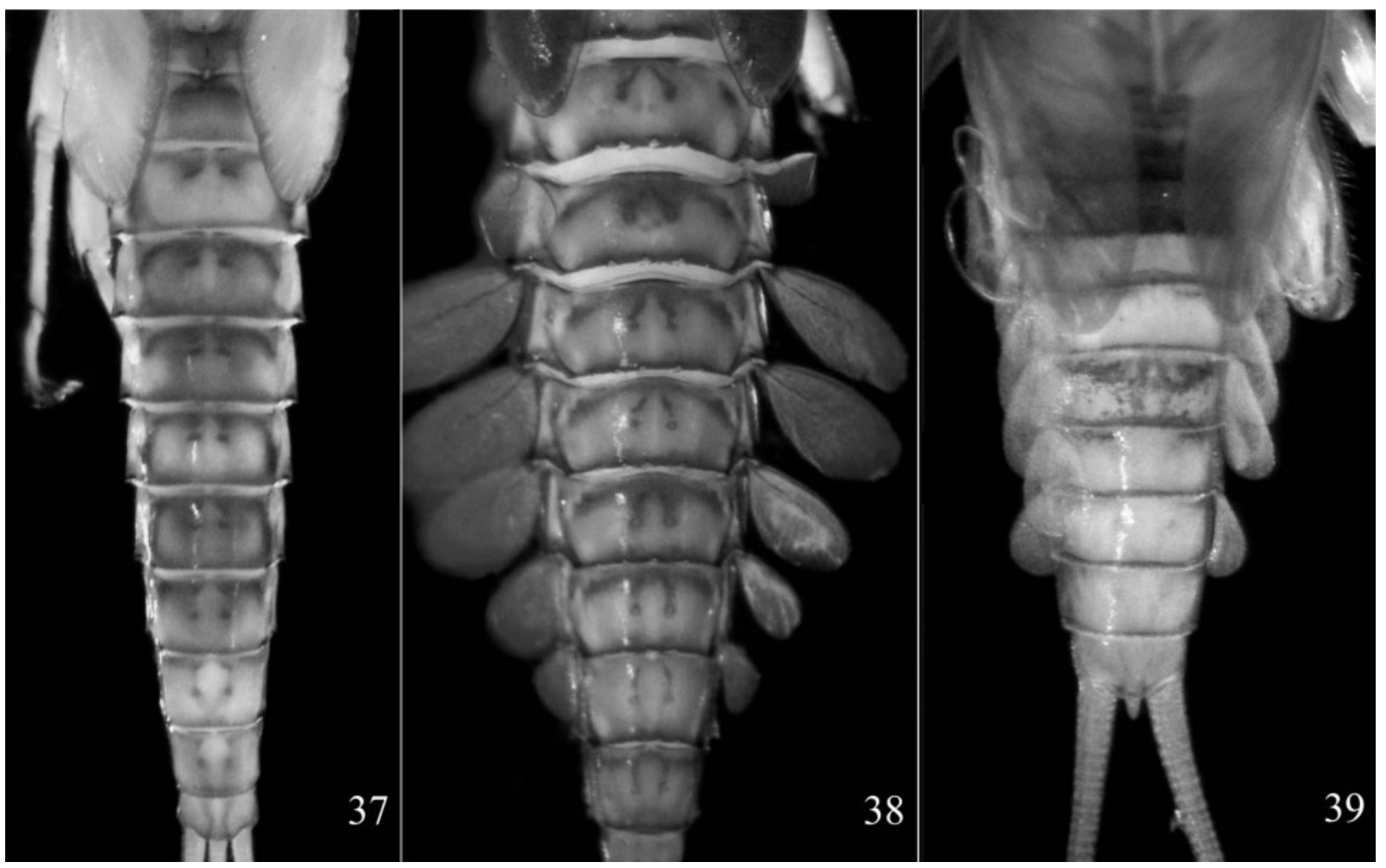

Figs 37-39. Camelobaetidius spp. n. Abdominal color pattern. 37. C. hamadae sp. n. 38. C. lassance sp. n. 39. C. maranhensis sp. n.

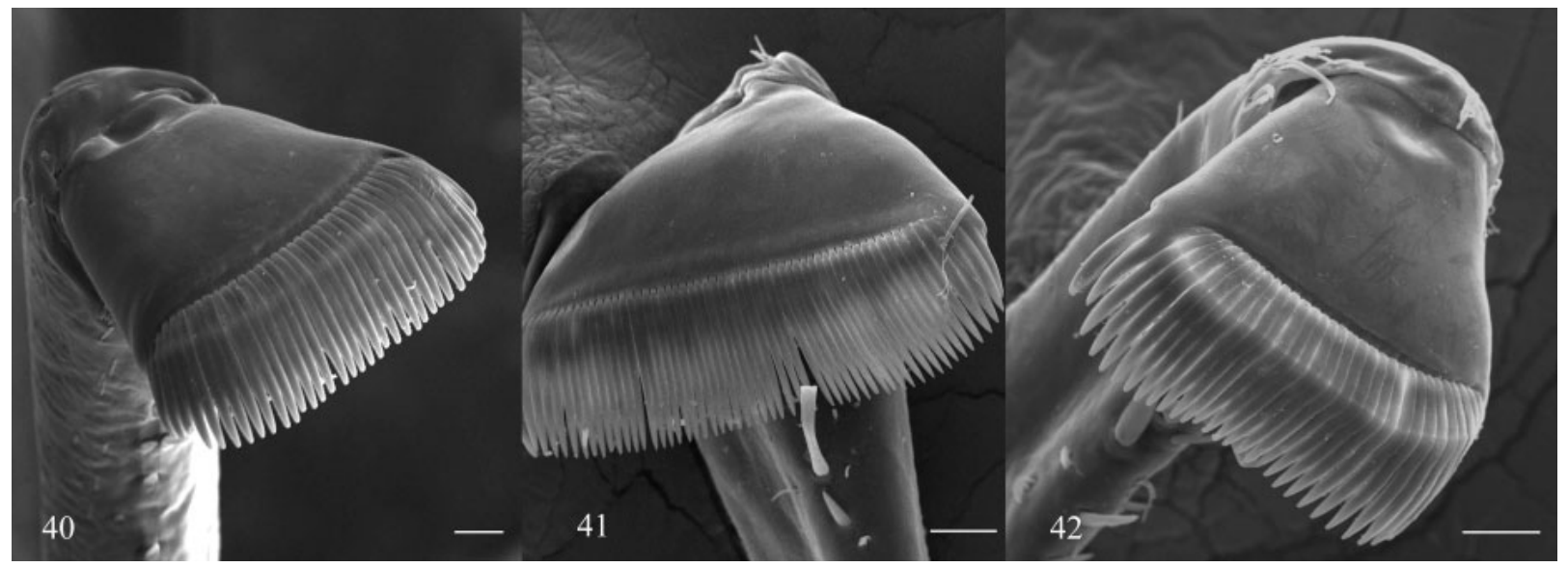

Figs 40-42. Camelobaetidius spp. n., SEM photographs. Claw of nymphs. 40. C. hamadae sp. n. 41. C. lassance sp. n. 42. C. maranhensis sp. n. Scale bars $=20 \mu \mathrm{m}$. 


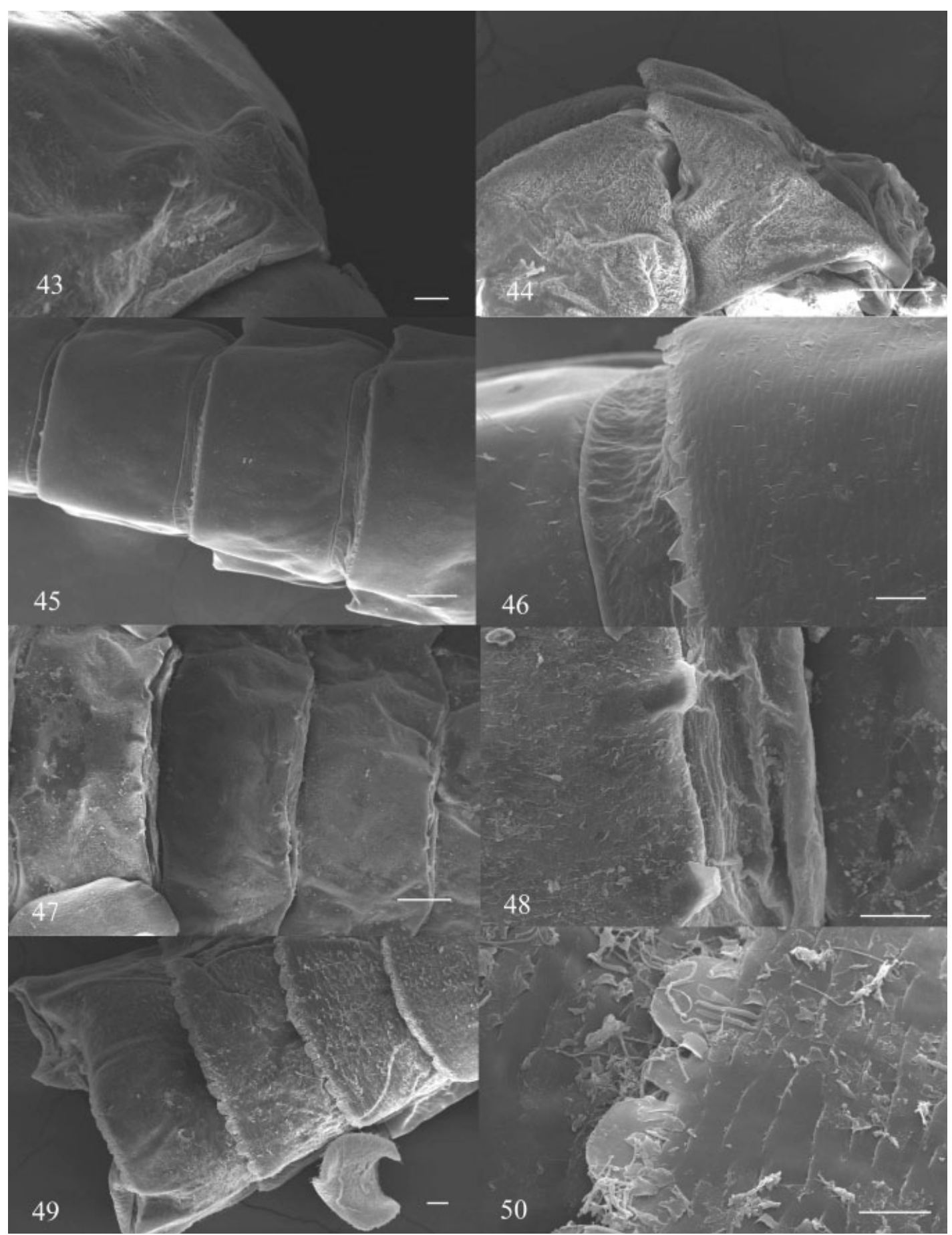

Figs 43-50. Camelobaetidius spp. n., SEM photographs. Nymphal thorax and abdomen. 43. C. lassance sp. n. (detail of tubercles on pronotum). 44. C. maranhensis sp. n. (detail of tubercles on pronotum). 45. C. hamadae sp. n. (partial view of abdominal terga). 46. C. hamadae sp. n. (detail of posterior margin of terga). 47. C. lassance sp. n. (partial view of abdominal terga). 48. C. lassance sp. n. (detail of posterior margin of terga). 49. C. maranhensis sp. n. (partial view of abdominal terga). 50. C. maranhensis sp. n. (detail of posterior margin of terga). Scale bars $=100 \mu \mathrm{m}$ (figs. 44-45, 47), $30 \mu \mathrm{m}$ (fig. 48), $20 \mu \mathrm{m}$ (figs. 43, 46, 49), $10 \mu \mathrm{m}$ (fig. 50). 
Etymology. We are pleased and honored to name this species after Dr. Neusa Hamada, our colleague in the field of aquatic entomology, and responsible for supplying us with the majority of the material treated in the present work.

Diagnosis : inner margin of the second segment of labial palp rounded, strongly produced (Figs. 8, 9) ; two thoracic gills present at base of forelegs (Fig. 11); claws with 36-37 denticles (Fig. 40) ; terminal filament about as long as cerci.

Brazilian records (Fig. 1): Corredeira do Mucujezinho, Palmeiras and Mucugê, Bahia State.

Remarks : $C$. hamadae sp. $\mathrm{n}$. is a distinctive species of Camelobaetidius. The presence of two thoracic gills at the base of forelegs is unique among species of the genus ; the shape of the second segment of the labial palp, and the morphology and setation of the labrum, are not usually found in species of Camelobaetidius with the terminal filament as long as the cerci. These characteristics are found in four other species, all of them with the terminal filament reduced. These include $C$. francischettii, $C$. mantis, $C$. leentvaari, and, to a lesser extent, $C$. ipaye Nieto.

Camelobaetidius janae Dominique \& Thomas in Dominique et al., 2001

Diagnosis : inner margin of the second segment of labial palp rounded, strongly produced ; maxillary palp bifid ; thoracic gill absent at base of forelegs ; claws with approximately 21 denticles ; terminal filament about as long as cerci.

Brazilian records (Fig. 1) : Nova Xavantina, Mato Grosso State ; Guajará-mirim, Rondônia State.

Remarks : This species was originally described based on nymphs from French Guiana (Dominique et al. 2001). Salles et al. (2004) reported some nymphs from the state of Mato Grosso, West-Central Brazil. In the present paper, we present data for material collected from the state of Rondônia, Northern Brazil.

Material examined : Rondônia, Guajará-mirim, Rio Mamori, 11/ix/2002, N. Hamada leg, 2 nymphs.

Camelobaetidius lassance Salles \& Serrão, sp. n. (Figs. 1, 14-25, 38, 41, 43, 47-48)

Mature nymph. Body length : 4.4-5.8 mm. Caudal filaments length : 1.7-2.0 $\mathrm{mm}$.

Head. General coloration pale brown, with brownish marks as in Fig. 14. Turbinate portion of male compound eyes brown. Antennae with scape and pedicelum whitish brown, flagellum brown. Labrum (Fig. 15) with two to three lateral, long, fine, simple setae, and with one submedial long, fine, simple setae ; intermediary setae absent. Hypopharynx as in Fig. 16. Left mandible (Fig. 17) with incisors with eight denticles ; prostheca robust, apically denticulate; one minute, acute seta, between prostheca and subtriangular process. Right mandible (Fig. 18) with incisors with seven denticles ; prostheca robust, narrower than left prostheca ; 3 minute, acute setae, between prostheca and mola. Maxillae (Fig. 19) with palp segment one medially produced; segment two subequal in length to segment one ; medial hump with one fine, simple, setae ; apex of galea-lacinia small, with few setae. Labium (Figs. 21, 22) with glossae with six fine, simple setae medially, and five to six fine, simple setae distally ; paraglossae slightly longer than glossae, apically with two rows of long, apically pectinate setae, dorsally with two robust, simple setae ; segment two of labial palp with proximal margin of distomedial process slightly concave and apical margin convex, culminating in a small finger like process, outer margin with few, fine, simple setae, and dorsally with three long, fine, simple setae ; segment three scattered with long, fine, simple setae over surface.

Thorax. Pro, meso, and metanotum yellowishbrown, marked with brown; pronotum color pattern as in Fig. 10 ; pro and mesonotum eventually with two small tubercles at posterior margin (Fig. 43), more common in younger nymphs. Pleurae brown. Sterna yellowish-white. Legs (Fig. 23) without thoracic gills at base ; femora yellowish-white, outlined with dark brown, except for ventral margin, and marked with brown as in Fig. 23 ; tibiae light brown, ventral margin scattered with approximately four short, acute, simple setae plus two short, acute, simple setae at apex ; tarsi light brown at base, becoming darker distally, with inner margin with four short, acute, simple setae, one subdistal long, robust, simple seta, and one distal robust, simple setae ; claws (Fig. 41) with 59-62 denticles.

Abdomen. General coloration yellowish-brown, with brown marks as in Fig. 38. Posterior margin of terga (Figs. 47, 48) with three to four large and elevated spines. Sterna yellowish-white. Gills (Fig. 24) whitish, with margins and main trachea brownish. Paraprocts as in Fig. 25. Terminal filament about as long as cerci.

Adults. Unknown.

Type material. Holotype : female mature nymph, body in alcohol, legs and mouthparts mounted on slides. Brazil, Minas Gerais State, Lassance, Rio das Velhas, 17'52'25.8' S, 4432'56.2' W, 31-vii-2003, F.F. Salles, N. Hamada, S.R.M. Couceiro, J.O. Silva (INPA). Paratypes : 16 nymphs, same data as holotype (4 
nymphs in IFML, 4 in INPA, 4 in MNRJ) ; one nymph, São Paulo State, Valparaíso, 21 ${ }^{\circ} 27^{\prime} 16,6^{\prime}$ S, $50^{\circ} 55^{\prime} 03,7^{\prime \prime} \mathrm{W}$ (INPA).

Etymology. Name of the city where most of the material was collected.

Diagnosis : segment two of labial palp with proximal margin slightly concave and apical margin convex, culminating in a small finger like process (Figs. 2122) ; thoracic gill absent at base of forelegs (Fig. 23) ; claws with approximately 60 denticles (Fig. 38) ; posterior margin of terga with few, large and elevated spines (Figs. 47-48) ; terminal filament about as long as cerci.

Brazilian records (Fig. 1) : Lassance, Minas Gerais State ; Valparaíso, São Paulo State.

Remarks : C. lassance sp. n. has approximately 60 denticles on the claw, which is the highest number found on any Camelobaetidius species. Besides this characteristic, the posterior margin of the terga, with few, large and elevated spines, is also exclusive among Camelobaetidius. The small tubercles on the posterior margin of the pro and mesonotum are absent in mature nymphs. However, this characteristic may help in the identification of younger nymphs of $C$. lassance $\mathrm{sp} . \mathrm{n}$. The morphology of the second segment of the labial palp is also very characteristic, and resembles the labial palp of $C$. ortizi Dominique \& Thomas. However, several other characteristics, such as body size, number of denticles on the claws, among others (see Dominique \& Thomas 2002), separates this French Guyanese species from $C$. lassance $\mathrm{sp}$. $\mathrm{n}$.

\section{Camelobaetidius leentvaari Demoulin, 1966}

Diagnosis : segment two of labial palp with distomedial process rounded and strongly produced ; forefemora with prominent protuberance and foretibiae with an indentation at apex ; ventral margin of forefemora and foretibiae entirely scattered with spines ; small thoracic gill present at base of forelegs ; claws with 17 to 23 denticles ; prosternum with a single, medial protuberance ; and terminal filament as long as the length of the $10^{\text {th }}$ abdominal segment.

Brazilian records (Fig. 1) : Laranjal do Jari, Amapá State.

Remarks : C. leentvaari was described based on six nymphs from Suriname (Demoulin 1966). Traver \& Edmunds (1968) stated, based on Demoulin's figures, that this species probably possesses nine denticles on the claws, contrasting with the 25 denticles found in its sister species, $C$. mantis. However, the redescription of $C$. leentvaari, based on the type material and additio- nal nymphs from Brazil (Salles et al. 2005a), demonstrates that this species has 17 to 23 denticles on the claws, a number of denticles very close to those found in C. mantis.

Camelobaetidius mantis Traver \& Edmunds, 1968

Diagnosis : segment two of labial palp with distomedial process rounded ; forefemora with prominent protuberance and foretibiae with an indentation at apex, with spines on its margin; thoracic gill absent at base of forelegs ; claws with approximately 25 denticles ; gills with main trachea and few lateral branches pigmented ; terminal filament as long as the length of the $10^{\text {th }}$ abdominal segment.

Brazilian records (Fig. 1): Manaus, Amazonas State.

Remarks : This species was described based on one immature nymph from Manaus, Brazil (Traver \& Edmunds 1968). Thomas et al. (2003b) found two possible nymphs of $C$. mantis in French Guyana, but the specimens were immature and the identification was not confirmed. Salles et al. (2005a) have pointed out that the redescription of $C$. mantis based on its type material is needed. The simplicity of the original description and the similarity between the number of denticles on the claws of $C$. mantis and $C$. leentvaari (see above) confounds its identification at the present time.

Camelobaetidius maranhensis Salles \& Serrão, sp. n. (Figs. 1, 26-36, 39, 42, 44, 49-50)

Mature nymph. Body length : 2.7-3.1 mm. Caudal filaments length : 2.3-2.8 mm.

Head. General coloration brown, with brownish and whitish marks as in Fig. 26. Turbinate portion of male compound eyes orange. Antennae pale whitish-brown. Labrum (Fig. 27) with anterodorsal row of nine, fine, simple setae, becoming longer toward midline, and with few, subbasal, short, fine, simple setae. Hypopharynx as in Fig. 28. Left mandible (Fig. 29) with incisors with five denticles ; prostheca robust, apically denticulate ; two minute, acute setae, between prostheca and subtriangular process. Right mandible (Fig. 30) with incisors with six denticles; prostheca robust, apically denticulate ; one minute, acute seta, between prostheca and mola. Maxillae (Fig. 31) with palp segment one cylindrical ; segment two subequal in length to segment one ; medial hump with $1+1$ fine, simple, setae. Labium (Figs. 32, 33) with glossae with ten fine, simple setae medially ; paraglossae longer than glossae, apically with two rows of long, apically pectinate setae, dorsally with two robust, simple setae; segment two of labial palp with distomedial process rounded, inner margin with few, fine, simple setae, and dorsally 
with five long, fine, simple setae ; segment three scattered with few acute setae over surface.

Thorax. Pro and mesonotum light brown, color pattern of pronotum as in Fig. 10. Metanotum and pleurae yellowish. Sterna yellowish-white. Pronotum with medial pair of tubercles (Fig. 44). Legs (Fig. 35) with one thoracic gill at base ; femora yellowish-white, with brownish marks as in Fig. 35 ; tibiae yellowish-white, ventral margin scattered with acute, simple setae, becoming more abundant and longer at the apex, dorsal margin with row of short, fine, simple setae ; tarsi whitish at base, becoming brown toward apex, ventral margin with seven to eight long, acute, simple setae, one subdistal long, robust, simple seta, and one distal robust, simple setae ; claws (Fig. 42) with 31-32 denticles.

Abdomen. General coloration yellowish-brown, with brownish marks as in Fig. 39, in one female the first and second abdominal terga are lighter than in males. Posterior margin of terga (Figs. 49, 50) with subquadrate spines. Sterna yellowish-white, light brown at lateral margins. Gills (Fig. 34) whitish, with main trachea poorly pigmented. Paraprocts as in Fig. 36. Terminal filament shorter than the 10th abdominal segment.

\section{Adults. Unknown.}

Type material. Holotype : female mature nymph, body in alcohol, legs and mouthparts mounted on slides. Brazil, Maranhão, Riachão, Riacho Cocal, Cachoeira Santa Bárbara, 07²13'462''S, 46²7'246'W, 07/viii/2001, N. Hamada (INPA). Paratypes : three nymphs, same data as holotype (2 nymphs in INPA, 1 in IFML).

Etymology. After Maranhão, the name of the state where the species was found.

Diagnosis : inner margin of the second segment of labial palp rounded (Figs. 32-33) ; pronotum with medial pair of tubercles (Fig. 44); thoracic gill present at base of forelegs (Fig. 34) ; claws with 31-32 denticles (Fig. 39) ; terminal filament shorter than 10th abdominal segment.

Brazilian records (Fig. 1): Riachão, Maranhão State.

Remarks : Besides C. maranhensis sp. n., only C. tuberosus has tubercles on the pronotum. Nevertheless, nymphs of $C$. tuberosus also have a single blunt tubercle on the mesonotum and the terminal filament is not reduced as in $C$. maranhensis sp. n. Although younger nymphs of $C$. lassance sp. n. also possess small tubercles on pro and mesonotum, they are not posteriorlly pointed as those of $C$. maranhensis sp. n. and C. tuberosus.

\section{Camelobaetidius matilei Thomas \& Péru, in Tho- mas et al., 2003}

Diagnosis : segment two of labial palp with distomedial process poorly developed; apex of segment 3 of labial palp truncate ; hind wing pads absent ; thoracic gill absent at base of forelegs ; claws with 13-15 denticles ; terminal filament about as long as cerci.

Brazilian records (Fig. 1): Boa Vista, Roraima State.

Remarks : C. matilei was recently described based on nymphs from French Guyana (Thomas et al. $2003 \mathrm{~b}$ ). Besides being the first record of this species from Brazil, C. matilei is also reported for the first time from outside of French Guyana.

Material examined : Roraima, Boa Vista, Rio Cauamé, 24/x/2001, N. Hamada leg., 3 nymphs.

Camelobaetidius phaedrus (Traver \& Edmunds, 1968)

Diagnosis : incisors of mandible strongly protruded ; segment two of labial palp with distomedial process rounded ; thoracic gill present at base of forelegs ; claws with 7-11 denticles; terminal filament about as long as cerci.

Brazilian records (Fig. 1) : Ipumirim, Santa Catarina State ; Caçapava do Sul and Cachoeira do Sul, Rio Grande do Sul State.

Remarks : Traver \& Edmunds (1968) described this species based on nymphs from Brazil. Nieto (2003) recorded it from Argentina, and described the adults for the first time.

Camelobaetidius serapis (Traver \& Edmunds, 1968)

Diagnosis : segment two of labial palp with distomedial process pointed; small thoracic gill present at base of forelegs ; claws with 30-40 denticles ; terminal filament about as long as cerci ; length of body 4.5-5.0 $\mathrm{mm}$.

Brazilian records (Fig. 1): Ipumirim and Seara, Santa Catarina State.

Remarks : C. serapis, unlike the other South-American species described by Traver \& Edmunds (1968), has no other records since its original description. The species was described based solely on nymphs from Santa Catarina State, Brazil.

Camelobaetidius tuberosus Lugo-Ortiz \& McCafferty, 1999

Diagnosis : inner margin of the second segment of labial palp rounded; pronotum with medial pair of tubercles, and mesonotum with a single tubercle ; thora- 
cic gill present at base of forelegs ; claws with 15-17 denticles ; terminal filament about as long as cerci.

Brazilian records (Fig. 1) : Lassance, Minas Gerais State ; Nova Xavantina, Mato Grosso State.

Remarks : C. tuberosus was described based on one nymph from Paraguay (Lugo-Ortiz \& McCafferty 1999a). Nieto (2003) redescribed the species based on additional material from Argentina, and described the adults for the first time. We report this species for the first time from Brazil, extending the known distribution of $C$. tuberosus northward.

Material examined : Minas Gerais, Lassance, Rio das Velhas, $17^{\circ} 52^{\prime} 25.8^{\prime}$ 'S, 4432' 56.2' W, 31-vii2003, F.F. Salles, N. Hamada, S.R.M. Couceiro, J.O. Silva legs., 1 nymph. Mato Grosso, Nova Xavantina, Córrego Cachoeira, 16/vii/2004, H. Cabette leg., 1 nymph.

\section{KEY TO NYMPHS OF BRAZIL}

1. Terminal filament reduced, about the size of the 10th abdominal segment ...................... 2 1 '. Terminal filament not reduced, about as long as cer-

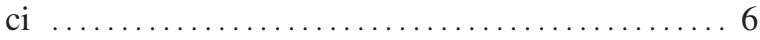

2. Forefemora with a prominent protuberance ..... 3

2 '. Forefemora without a protuberance ......... 5

3. Thoracic gill absent at base of forelegs ; prosternum without a medial protuberance ; gills with main trachea and few lateral branches pigmented........ C. mantis 3'. Small thoracic gill present at base of forelegs; prosternum with a medial protuberance; gills untracheated

...................................... 4

4. Claws with 17-23 denticles ......... C. leentvaari

4'. Claws with 35-37 denticles ...... C. francischettii

5. Pronotum with medial pair of tubercles

C. maranhensis sp. $\mathrm{n}$.

5'. Pronotum without tubercles ........... C. billi

6. Thoracic gill absent at base of forelegs ....... 7

6'. Thoracic gill present at base of forelegs ...... 10

7. Maxillary palp bifid ................ . janae

7'. Maxillary palp simple ................ 8

8. Claws with 13-18 denticles $\ldots . \ldots \ldots \ldots \ldots . . .9$

8'. Claws with approximately 60 denticles

C. lassance sp. $\mathrm{n}$.

9. Hind wing pads present; tarsal claw with 17-18 denticles ............................ cayumba 9'. Hind wing pads absent; claws with 13-15 denticles C. matilei
10. Two thoracic gills at base of forelegs

C. hamadae sp. n.

10'. One thoracic gill at base of forelegs ........ 11

11. Pro and mesonotum with tubercles ..C. tuberosus

11'. Thorax without tubercles $\ldots \ldots \ldots \ldots \ldots \ldots 12$

12. Claws with 7-11 denticles; incisors of mandible strongly protruded .................. phaedrus 12'. Claws with 20-40 denticles ; incisors not protru-

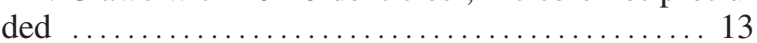

13. Claws with 30-40 denticles; thoracic gill at base of forelegs small .................... serapis 13'. Claws with 20-27 denticles; thoracic gill at base of forelegs of normal size ................ C. anubis

\section{Acknowledgements}

We sincerely thanks Dr. Neusa Hamada (Instituto Nacional de Pesquisas da Amazônia) for supplying part of the material, and for the opportunity gave to the first author to follow her in collecting trips throughout poorly documented areas of Brazil. We also thank Walandir Ferreira Filho for his invaluable help during a collecting trip in Lassance, Minas Gerais, and Dr. Elidiomar R. Da-Silva (Universidade do Estado do Rio de Janeiro), Dr. Carolina Nieto (FundaciÛn-Instituto Miguel Lillo), Dr. Luke Jacobus (Purdue University) and an anonymous referee for their comments on the manuscript. This work was supported by Brazilian Research Agencies CNPq and FAPEMIG. FFS is a doctoral student at the Universidade Federal de Viçosa (UFV) and JES is a staff member of UFV and research fellow from CNPq.

\section{References}

Demoulin G. 1966. - Contribution à l'étude des Ephéméroptères du Surinam. Bull. Inst. R. Sci. Nat. Belg., 42, 1-22.

Dominique Y., Mathuriau C., Thomas A. 2002. - Étude systématique du genre Camelobaetidius Demoulin, 1966 en Colombie [Ephemeroptera, Baetidae]. Bull. Soc. Hist. Nat. Toulouse, 137, 17-32.

Dominique Y., Thomas A., Orth K., Dauta, C. 2001. - Les Ephémères de La Guyane Française. 2. Camelobaetidius billi et $C$. janae n. spp (Ephemeroptera, Baetidae). Ephemera, 2, 39-48.

Dominique Y., Thomas, A. 2002. - Les Ephémères de la Guyane Française. 5. Description de Camelobaetidius ortizi n. sp. [Ephemeroptera: Baetidae]. Ephemera, 3, 27-32.

Lugo-Ortiz C.R., McCafferty W.P. 1999a. - An unusual new species of Camelobaetidius (Ephemeroptera : Baetidae) from Paraguay. Entomol. News, 110, 221-224.

Lugo-Ortiz C.R., McCafferty W.P. 1999b. - Revision of South American species of Baetidae (Ephemeroptera) previously placed in Baetis Leach and Pseudocloeon Klapálek. Ann. Limnol. - Int. J. Lim, 35, 257-262.

Nieto C. 2002. - Primera cita del género Camelobaetidius (Ephemeroptera : Baetidae) para Bolivia, con la descripción de una especie nueva. Rev. Soc.Entomol. Argentina, 61, 57-61.

Nieto C. 2003. - El género Camelobaetidius (Ephemeroptera : Baetidae) en la Argentina. Acta Zool. Mex. (Nueva Série), 88, 233 255.

Salles F.F., Andrade M.B., Da-Silva, E.R. 2005b. Camelobaetidius francischettii : a new species of Baetidae (Ephemeroptera) from Brazil. Zootaxa, 1027, 47-53.

Salles F.F., Dias L.G. 2004. - Descrição dos adultos de Camelobaetidius billi (Ephemeroptera, Baetidae). Iheringia, 94, 209-210. 
Salles F.F., Serrão J.E., Pereira, S.M. 2005a. Redescription of Camelobaetidius leentvaari Demoulin, 1966 (Ephemeroptera : Baetidae). Ephemera, 5, 69-75.

Thomas A., Dominique Y., Horeau V. 2003a. - Les Ephémères de la Guyane Française. 7. Redescription de Camelobaetidius cayumba (Traver \& Edmunds, 1968) [Ephemeroptera : Baetidae]. Epheme$r a, 3,117-122$.
Thomas A., Peru N., Horeau V. 2003b. - Les Ephémères de la Guyane Française. 8. Description de Camelobaetidius matilei $\mathrm{n}$. sp. et clé de détermination des espèces guyanaises de ce genre [Ephemeroptera : Baetidae]. Ephemera, 3, 123-133.

Traver J.R., Edmunds G.F., Jr. 1968. - A revision of the Baetidae with spatulate-clawed nymphs (Ephemeroptera). Pac. Insects, 10, 629-677. 